\title{
DEVELOPMENT OF THE EXTRACTION METHOD OF INACTIVE FORMS OF PECTIN SUBSTANCES FROM FRUITS TO EASY-DIGESTIBLE ACTIVE FORM DURING THE OBTAINING OF NANOFOOD
}

\author{
Viktoriya Pogarska \\ Department of Technology processing of fruits, vegetables and milk \\ Kharkiv State University of Food Technology and Trade \\ 333 Klochkivska str., Kharkiv, Ukraine, 61051 \\ ktppom@ukr.net \\ Raisa Pavlyuk \\ Department of Technology processing of fruits, vegetables and milk \\ Kharkiv State University of Food Technology and Trade \\ 333 Klochkivska str., Kharkiv, Ukraine, 61051 \\ Roman David Tauber \\ Department of Academy of hospitality and catering \\ Academy of hotel management and catering industry in Poznan \\ 19 Nieszawska str., Poznan, Poland, 61-022 \\ wshigua@i.ua. \\ Aleksey Pogarskiy \\ Department of Technology processing of fruits, vegetables and milk \\ Kharkiv State University of Food Technology and Trade \\ 333 Klochkivska str., Kharkiv, Ukraine, 61051 \\ Adelina Berestova \\ Department of Technology processing of fruits, vegetables and milk \\ Kharkiv State University of Food Technology and Trade \\ 333 Klochkivska str., Kharkiv, Ukraine, 61051 \\ Tetyana Kravchuk \\ Department of health resort business \\ National Academy of food technologies \\ 112 Kanatna str., Odessa, Ukraine, 65039 \\ krytan@ukr.net \\ Tetyana Stukonozhenko \\ Department of Technology processing of fruits, vegetables and milk \\ Kharkiv State University of Food Technology and Trade \\ 333 Klochkivska str., Kharkiv, Ukraine, 61051 \\ tasichkayo@gmail.com \\ Iuliia Kakadii \\ Department of Technology processing of fruits, vegetables and milk \\ Kharkiv State University of Food Technology and Trade \\ 333 Klochkivska str., Kharkiv, Ukraine, 61051 \\ ykakadiy@ukr.net
}

Abstract

The aim of the work is development of a unique method for deep processing of fruits and vegetables with a high content of sparingly soluble pectin substances, which makes it possible to remove pectic substances from inactive form and transform them into an easily digestible active form when obtaining natural semi-finished products and food products in nanosized form. To achieve 
the aim, a complex effect on the raw material of steam-thermal treatment or cryogenic shock freezing and fine-dispersed grinding is used as an innovation.

A new method for obtaining finely dispersed additives and health products from fruits and vegetables with a high content of biologically active substances (BAS) and prebiotic substances is developed, which is based on a complex effect on raw materials of processes of steam-thermal or cryogenic treatment of raw materials and fine-dispersed grinding, which is accompanied by destruction, mechanochemistry, non-enzymatic catalysis. It is found that when these processes are activated, pectic substances are activated, more complete extraction from raw materials (4.5 $\quad 7.3$ times) from a latent form and transformation into a soluble form. The mechanism of these processes is disclosed, recommendations for the creation of recreational nanoproducts are developed. It is shown that, in parallel, non-enzymatic catalysis (up to $70 \%$ ) of hardly soluble pectic substances in individual monomers takes place, that is, transformation into a soluble, easily digestible form.

The increase and seizures of latent forms of biologically active substances in finely dispersed frozen and heat-treated purees from fruit compared with fresh raw materials is established. The increase is respectively 1.5 ...4.0 times and 1.5 ...3.0 times. The quality of the obtained new types of fine mashed potatoes exceeds the known analogs for BAS content and technological characteristics. New types of purees are in a nanoscale, easily digestible form.

With the use of new types of finely dispersed additives, a wide range of products for health-improving nutrition has been developed with a record content of natural BASs (new types of nano-lipids, nanosorb products, milk-vegetable cocktails, fillings for confectionery and extruded products, curd desserts, bakery products, snacks - falafel, creams, etc.).

Keywords: non-enzymatic catalysis 1 , mechanolysis 2 , heat treatment 3, cryotreatment 4, nanocomplex 5, heteropolysaccharides 6 , pectin substances 7 , fruits 8 , vegetables 9 , health products 10 . Adelina Berestova, Tetyana Kravchu, Tetyana Stukonozhenko, Iuliia Kakadii

\section{Introduction}

Today in Ukraine and other countries of the world, there is a shortage of high-quality natural supplements from fruit and vegetable pectin-rich raw materials, which are also carriers of curative biologically active substances (BAS). Deficiency is associated with inadequate supply of dietary supplements, such as vitamins, carotenoids, minerals, proteins, etc., as well as indigestible food components, in particular pectin substances, cellulose, etc. They are responsible for immunity. The population's need for these substances in the world is only $50 \%$ satisfied. [1-3]. It is also known that pectin substances, cellulose, inulin and other refer to prebiotics that support the gastrointestinal tract in a healthy state. It is known that the health status of the population, as well as its immune system, is $80 \%$ dependent on maintaining the intestines in a healthy state. Such supplements are now needed to create products for healthy nutrition [4-8].

In the most developed countries, the problem of immunodeficiency is solved by introducing in the diets of food products and additives, especially from fruit and vegetable raw materials, which is characterized by a large number of BAS and prebiotics.

The aim of the work is development of a unique method for deep processing of fruits and vegetables with a high content of sparingly soluble pectin substances, which makes it possible to remove pectic substances from inactive form and transform them into an easily digestible active form when obtaining natural semi-finished products and food products in nanosized form.

\section{Materials and methods of research for the content of pectin substances and other BASs and biopolymers}

To achieve the aim, it is suggested to use a complex effect on the raw material of steam-thermal treatment as an innovation (in a modern apparatus - a convection oven) or cryogenic "shock" freezing and finely divided grinding to activate and remove hardly soluble inactive pectin substances and low molecular weight biologically active substances in a free soluble form .

Kharkiv State University of Food Technology and Trade (Kharkov, Ukraine) in cooperation with the Academy of Hotel Management and Catering Industry in Poznan (Poland) and Odessa National Academy of Food Technologies (Odessa, Ukraine) develop a fundamentally new unique method for deep processing of pectin mills fruits and vegetables. The method allows not only to 
maximally preserve, but also more fully utilize the biological potential inherent in plant raw materials and to transform BASs and pectin substances from the bound state into a nanostructure. The method is based on the process of steam-thermal mechanodestruction and cryomechanical degradation - non-enzymatic catalysis-mechanolysis (destruction of nanocomplexes in which biologically active substances and pectin are in a latent form) in cryoids or thermal decompositions of plant raw materials, which leads to the production of a nanosized product.

Steam thermal treatment of samples of apples, apricots and pumpkins was carried out in a steam convection oven ("Unox", Italy) at $105^{\circ} \mathrm{C}$ in a furnace, in the product $-70 \ldots 75^{\circ} \mathrm{C}$. Fine chopping was carried out in a cutter (Robot Coupe, France) (Fig. 1).

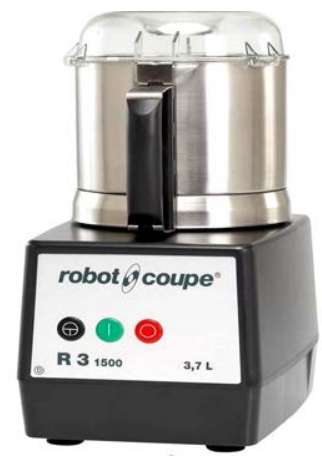

$a$

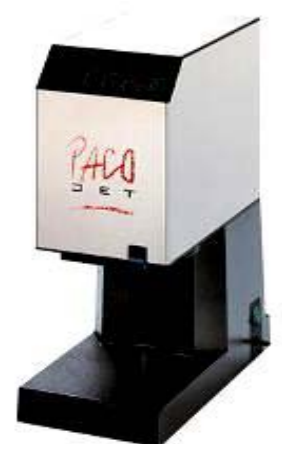

b

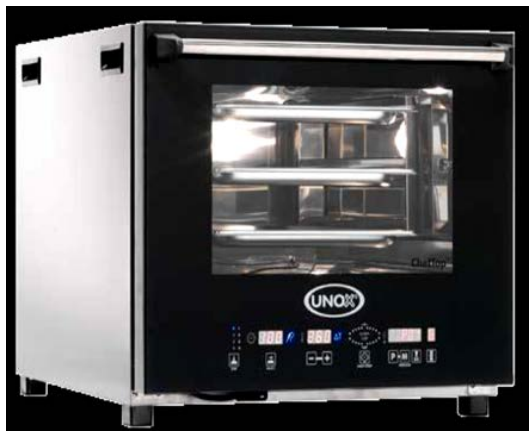

c

Fig. 1. Equipment used during research: $a$ - cutter for finely divided grinding; $b$ - low-temperature cutter; $c$ - steam convection oven

In researches, fresh fruit and vegetable raw materials (blackcurrant, apricots, lemons with zest, apples, pumpkin, spinach) containing hardly soluble heteropolysaccharide nanocomplex were used as the objects (Fig. 2). 


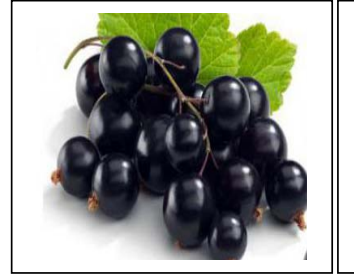

$a$

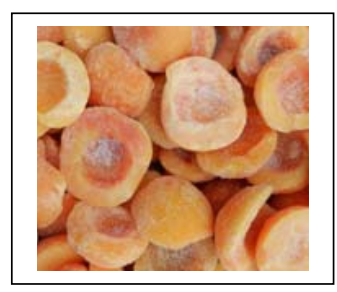

$d$

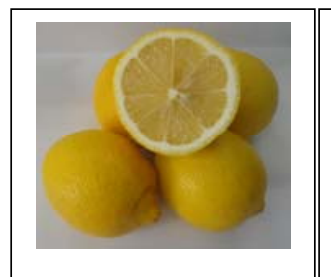

$g$

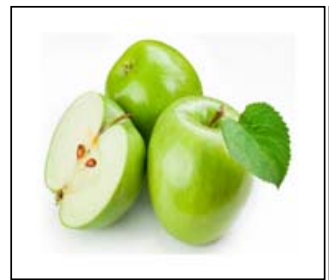

$j$

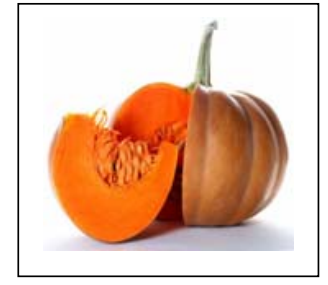

$m$

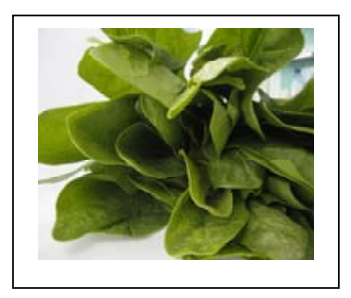

$p$

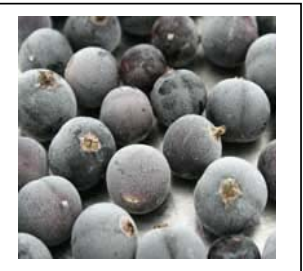

$b$

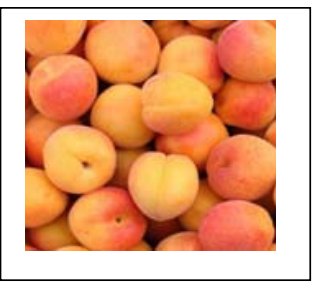

$e$

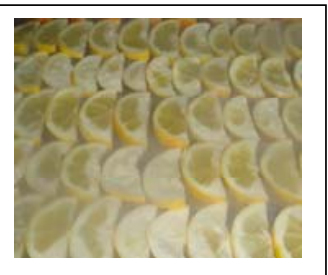

$h$

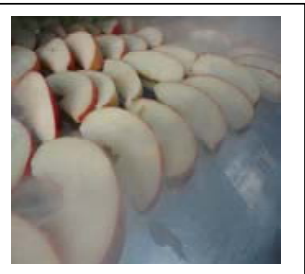

$k$

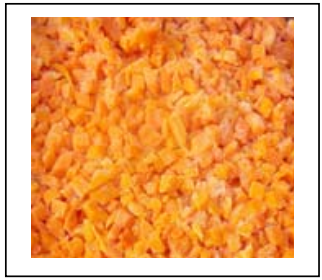

$n$

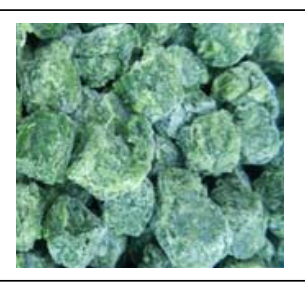

$r$

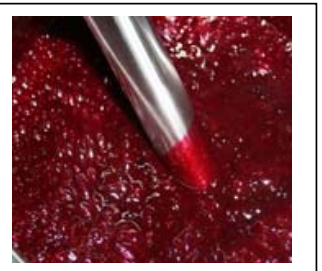

c

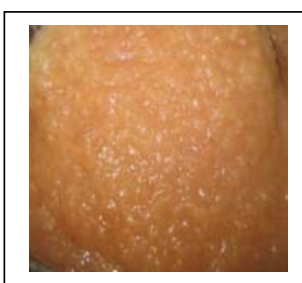

$f$
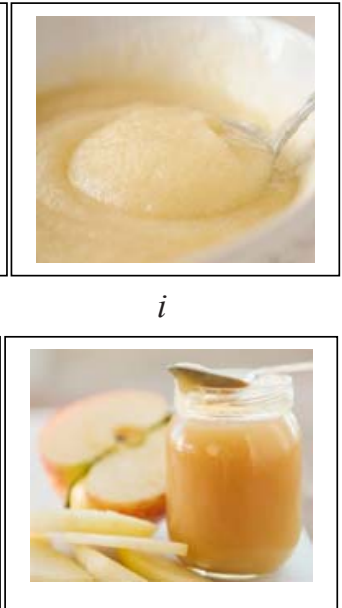

l

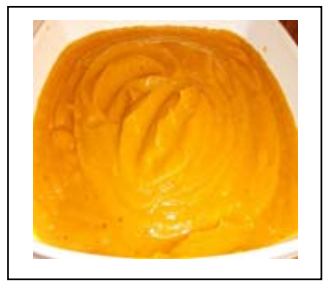

$O$

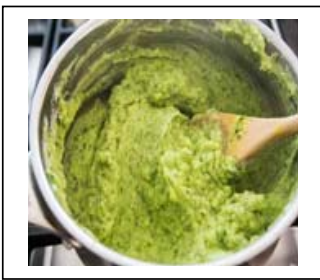

$q$

Fig. 2. Objects of research: $a$ - fresh black currant, $b$ - frozen black currant, $c$ - black currant nanopuree; $d$ - fresh apricots, $e$ - frozen apricots, $f$-nanopuree from apricots; $g$ - fresh lemons, $h$ - frozen lemons, $i$ - nanopuree from lemons and zedra; $j$ - fresh apples, $k$ - frozen apples, $l$ - nanopuree with apples; $m$ - fresh pumpkin, $n$ - frozen pumpkin, $o$ - nanopuree from pumpkin; $p$ - fresh spinach, $r$ - frozen spinach, $q-$ nanopuree from spinach 
In addition, finely dispersed additives in the form of heat-treated or cryopreserved nano-fruits from fruits and vegetables and products for health-improving nutrition (nanobeverages, nano ice cream, fillings for confectionery products, etc.) are studied (Fig. 3).
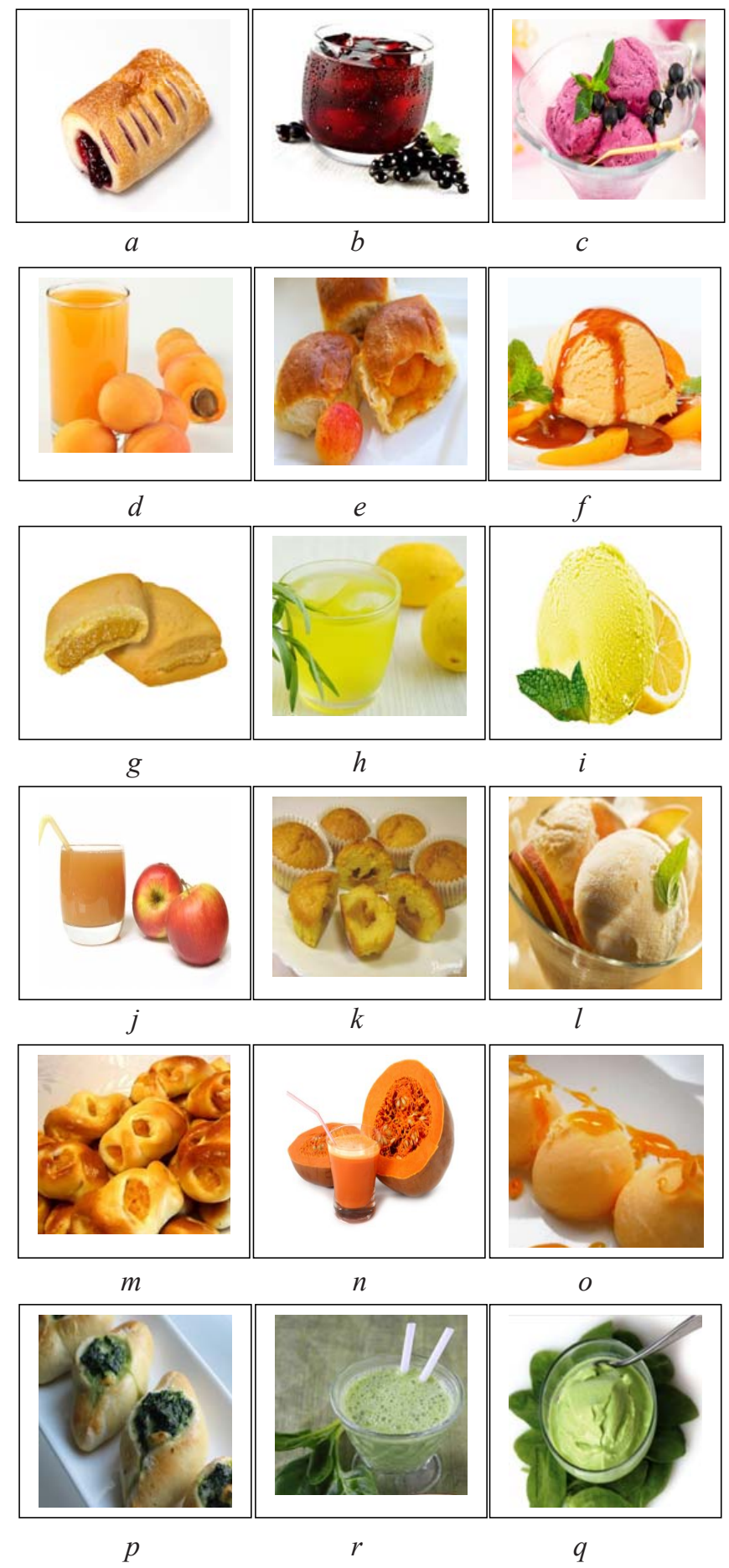

Fig. 3. New developed products for healthy nutrition using nanopuree from fruits and vegetables: $a, e, g, k, m, p$-confectionery products with filling;

$b, d, h, j, n, r$-nanobeverages; $c, f, i, n, m$ - nano ice cream;

$a, b, c$ - products from black currant; $d, e, f$-products from apricots;

$g, h, i$ - products from lemons; $j, k, l$-products from apples;

$m, n, o$ - products from the pumpkin; $p, r, q$-products from spinach 


\section{Experimental procedures}

Steam thermal treatment of samples of apples, apricots and pumpkins was carried out in a steam convection oven ("Unox", Italy) at $105{ }^{\circ} \mathrm{C}$ in a furnace, in the product $-70 \ldots 75^{\circ} \mathrm{C}$. Fine pulverization was carried out in a cutter ("Robot Coupe", France) and a low-temperature cutter ("SIRMAN", Italy).

In fresh fruits, berries and vegetables (black currant, apricots, lemons with zest, apples, pumpkin, spinach), heat-treated and frozen to the freezing temperature of the product $(-32 \ldots-35 \mathrm{C})$, as well as in finely-dispersed puree (storage temperature $-18{ }^{\circ} \mathrm{C}$ for 12 months without loss of vitamins and other BASs) from the fruit and vegetable raw materials the quality of the content of the basic BASs and prebiotic substances is determined.

The control is carried out according to the content of biologically active substances

- Low-molecular phenolic compounds (according to routine and for chlorogenic acids separately), determined by the Folin-Denis colorimetric method in terms of chlorogenic acid [4, 5].

- Tanning substances (by tannin), determined by the titrimetric method in terms of tannin. The method is based on the property of tannins to be oxidized in the presence of an indigo carmine indicator $[4,5]$.

- L-ascorbic acid, determined by visual and potentiometric titration with a solution of 2,6-dichlorophenolindophenolate $\mathrm{Na}[4,5]$.

- $\beta$-carotene, monitored by the Moure colorimetric method after extracting carotene from the product with an organic solvent and purifying the carotene from the accompanying coloring substances by column chromatography $[4,5]$.

In addition, the prebiotic substances are identified such as pectin (in particular, common pectin substances, soluble pectin and protopectin - insoluble pectin), cellulose, protein.

Chemical, physical-chemical and spectroscopic methods of research are used for BASs control in the research objects, which are reflected in $[4,5,9,10]$.

\section{Results}

On the basis of experimental studies, nanotechnology of frozen or steam thermal treated fine-dispersed additives from fruits, berries and vegetables (black currant, apricots, lemons with zest, apples, pumpkin, spinach), which differs from the traditional using high freezing rates using liquid or gaseous nitrogen, as well as fine-dispersed grinding.

It is shown that when these processes are activated, pectic substances are activated, more complete extraction from raw materials (4.5...7.3 times) from a latent form, and transformation into a soluble form. The mechanism of these processes is disclosed and recommendations for the creation of recreational nanoproducts are developed. It is shown that, in parallel, non-enzymatic catalysis (up to $70 \%$ ) of hardly soluble pectic substances in individual monomers takes place, that is, transformation into a soluble, easily digestible form.

The increase and seizures of latent forms of biologically active substances in finely dispersed frozen and heat-treated purees from fruit compared with fresh raw materials is established. The increase is respectively 1.5...4.0 times and 1.5 ...3.0 times. The quality of the obtained new types of finely dispersed puree exceeds the known analogs for BASs content and technological characteristics. New types of purees are in a nanoscale, easily digestible form. 


\section{Conclusions}

A new method for obtaining finely dispersed additives and health products from fruits and vegetables with a high content of BASs and prebiotic substances is developed. This method is based on a complex effect of processes of steam thermal or cryogenic treatment of raw materials and fine-dispersed grinding on raw materials, which is accompanied by destruction, mechanochemistry, and non-enzymatic catalysis.

It is found that when these processes are activated, pectic substances are activated, more complete extraction from raw materials (4.5..7.3 times) from a latent form, and transformation into a soluble form. In parallel, non-enzymatic catalysis of sparingly soluble pectic substances in individual monomers (up to $70 \%$ ) occurs, i. e., transformation into a soluble, easily digestible form.

The increase and seizures of latent forms of biologically active substances in finely dispersed frozen and heat-treated purees from fruit compared with fresh raw materials is established. The increase is respectively 1.5...4.0 times and 1.5 ...3.0 times. The quality of the obtained new types of finely dispersed puree exceeds the known analogs for BASs content and technological characteristics. New types of purees are in nanoscale, easily digestible form.

With the use of new types of finely dispersed additives, a wide range of products for health-improving nutrition has been developed with a record content of natural BASs (new types of nano-lipids, nanosorb products, milk-vegetable cocktails, fillings for confectionery and extruded products, curd desserts, bakery products, snacks - falafel, creams, etc.), in particular, fillings for confectionery products "pankake" and extruded products, which, within the framework of 2 economic contracts, were introduced into production (Confectionery firm “Lisova Kazka “, Kharkiv, Ukraine). Also, vitaminized health-improving nanobeverages and nanosorbents have been developed, which were made in production conditions in the SPE "KRIAS" and SPE "KhPK" (Kharkiv, Ukraine).

\section{References}

[1] Golubev, V. N. Sheluhina N. P. (1995). Pektin: himija, tehnologija, primenenie. Moscov: ATN, 387.

[2] Pavljuk, R. Ju., Pogarskaja, V. V., Pavljuk, V. A., Radchenko, L. A., Jur'eva, O. A., Maksimova, N. F. (2015). Krio- i mehanohimija v pishhevyh tehnologijah. Har'kovskij gosudarstvennyj universitet pitanija i torgovli; Har'kovskii torgovo-ekonomicheskij institut; Kievskskij nacional'nyj torgovo-ekonomicheskii universitet, 255.

[3] Gibson, G., Roberfroid, M. (2008). Handbook of Prebiotics. Vol. 4. CRS Press, London, 22-42.

[4] Pavliuk, R. Iu. Poharska, V. V. Radchenko, L. O. Pavliuk, V. A. Tauber, R. D. Tymofieieva, N. M. Bessarab, O. S. Bilenko, L. M. Yur,yeva O. O. ta in. (2017). Novyi napriamok hlybokoi pererobky kharchovoi syrovyny. Kharkiv: Fakt, 380.

[5] Pavlyuk, R., Pogarska, V., Radchenko, L., Roman, D. T., Timofeyeva, N., Kotuyk, T. (2016). The new method of processing of carotene-containing vegetables for the production of nanoproducts using combi-steamers and fine-dispersed comminution. EUREKA: Life Sciences, 3, 44-49. doi: 10.21303/2504-5695.2016.00146

[6] Kaprel'yanc, L. V. (2015). Prebiotiki: himija, tehnologija, primenenie. Kyiv: JenterPrint, 252. 
[7] Sousa, V. M. C. de, Santos, E. F. dos, Sgarbieri, V. C. (2011). The Importance of Prebiotics in Functional Foods and Clinical Practice. Food and Nutrition Sciences, 2 (2), 133-144. doi: 10.4236/ fns.2011.22019

[8] Bezusov, A. T., Malkova, M. H. (2010). Tekhnolohiia vyrobnytstva halakturonovykh olihosakharydiv iz pektynvmisnoi syrovyny, Kharchova nauka i tekhnolohiia, 1 (10), 58-61.

[9] Burana-osot, J., Soonthornchareonnon, N., Hosoyama, S., Linhardt, R. J., Toida, T. (2010). Partial depolymerization of pectin by a photochemical reaction. Carbohydrate Research, 345 (9), 12051210. doi: 10.1016/j.carres.2010.04.007

[10] Schols, H., Ros., I. (1998). Structural features of native and commercialle extracted pectins, cums and stabilizers for the food industries. The Royal Society of Chemistry. Wrexham, 10-15. 